\title{
En hånd å holde i
}

\author{
Kan internett og Google konkurrere \\ med legene? I TV-programmet \\ Hva feiler det deg? konkurrerte \\ tre googlere med legene Astrid \\ Nylander Almaas, Elisabeth \\ Holmboe Eggen og Wasim Zahid. \\ Det gikk lenge bra for dem som \\ stilte diagnoser via nettet.
}

Da jeg en periode hadde smerter og andre symptomer, ble det antydet systemisk lupus erythematosus (SLE). Jeg var helt ukjent med sykdommen. Før den dagen kunne lupus like gjerne vært et fjell, en plante eller et insekt. Vet dere hva det første jeg gjorde da jeg kom hjem fra fastlegen var? Jeg googlet. Nettet var fullt av lupus. Over 30 millioner treff. I den første artikkelen fikk jeg vite at det store flertallet av dem som rammes av lupus dør innen fem år.

Ikke bare fikk 40-årslaget jeg var invitert til en brå stopp for meg, men også troen på fremtiden. I alle fall der og da. For frem til dette søket på nettet - et sted som fôrer oss med informasjon 24 timer i døgnet hadde hodet fungert tilfredsstillende på tross av plager.

Da jeg leste prognosen, forsvant resten av informasjonen. Og den var langt viktigere enn det jeg hadde festet meg ved. For selv om jeg var i 2007, førte en setning hodet mitt flere tiår tilbake i tid. Før kortisonen og håpet - som omtales i andre artikler - men som jeg ikke oppdaget for bare den ene setningen om historikk.

Vi pasienter er som journalister. Uansett hvor mye du sier til en journalist, så har han oppfølgingsspørsmål: Hva, hvordan, hvorfor? Dere aner ikke hvor mange spørsmål jeg hadde for ni år siden. Men jeg hadde ingen å snakke med. Mine tilmålte minutter hos fastlegen var brukt opp. Og hvor ofte kan en pasient oppsøke en travel lege? Bare for å stille spørsmål? Svarene skulle jo komme fra Rikshospitalet noen måneder senere.

Heldigvis slapp jeg å tenke mer på dette etter to år med utredning...

Før LHL Hjerneslag ble etablert, gjennomførte vi fokusgrupper med slagrammede og pårørende, en kvalitativ metode for å bringe frem deltakernes oppfatninger, holdninger og ideer. To temaer var dominerende og går stadig igjen: behovet for informasjon og noen å snakke med. Muligheten til å stille spørsmål. Muligheten til å få svar. Allerede mens de pårørende sitter på sykehuset og venter på nytt om sin kjære, sier mange at de opplever informasjonssvikt. De trenger noen å snakke med, og noen trenger en hånd å holde i. For mange blir ikke den erfaringen bedre når hverdagen melder seg og små og store spørsmål og utfordringer dukker opp.

Svaret er ikke at legene skal bli samtalepartnere for over fem millioner nordmenn. Men vi får ikke et effektivt helsevesen med ineffektiv pasienthåndtering. Det er i pasientens kropp svarene ligger. Vellykket pasient- håndtering er å møte pasientene med god informasjon og dialog. Ingen kan forvente å få diagnosen og hele det videre pasientforløp i første konsultasjon, men man må føle seg ivaretatt og tatt på alvor, og man må gis mulighet til å se en vei videre.

Fastlegene kan også bli mer proaktive. Tenk hvor mye hjelp det er for en syk om legen uoppfordret spør om hvordan han føler seg og hva han tenker om fremtiden?

Rådgivingstelefoner med fagfolk som svarer på spørsmål er blitt godt mottatt. I forståelse med og i samarbeid med helsevesenet og helsemyndighetene kan slike tjenester videreutvikles som supplement og avlastning for mange travle fastleger.

Nordmenn er svært opptatt av helse, ifølge TNS Gallups siste helsepolitiske barometer. I tidligere nevnte TV-program klarte de tre googlerne seg godt lenge. Men når det strammet seg til i konkurransen, ble de slått av legene. Bare leger skal stille diagnoser.

Vi skal bruke internett, teknologi og ny teknologi til å gi informasjon og ha dialog. Men vi kommer aldri helt bort fra at det må sitte en levende hjerne og et varmt hjerte og en varm hånd i den enden som gir svarene, enten det er på fastlegekontoret, på telefonen eller på nettet.

\section{Tommyseor}

